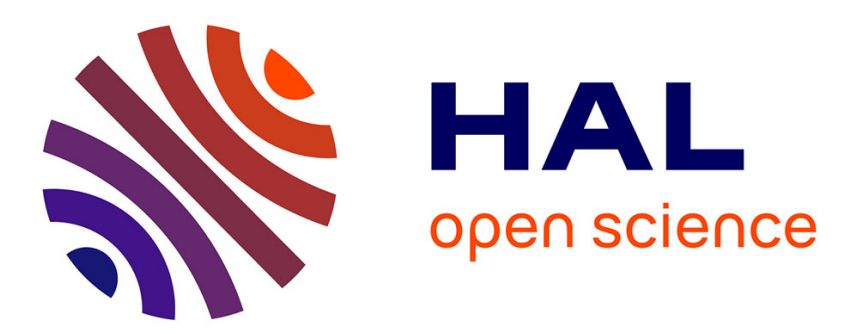

\title{
Reduction of Fusarium head blight and deoxynivalenol in wheat with early fungicide applications of prothioconazole
}

\author{
Simon G Edwards, Nigel Godley
}

\section{- To cite this version:}

Simon G Edwards, Nigel Godley. Reduction of Fusarium head blight and deoxynivalenol in wheat with early fungicide applications of prothioconazole. Food Additives and Contaminants, 2010, 27 (05), pp.629-635. 10.1080/19440040903515942 . hal-00591169

\section{HAL Id: hal-00591169 \\ https://hal.science/hal-00591169}

Submitted on 7 May 2011

HAL is a multi-disciplinary open access archive for the deposit and dissemination of scientific research documents, whether they are published or not. The documents may come from teaching and research institutions in France or abroad, or from public or private research centers.
L'archive ouverte pluridisciplinaire HAL, est destinée au dépôt et à la diffusion de documents scientifiques de niveau recherche, publiés ou non, émanant des établissements d'enseignement et de recherche français ou étrangers, des laboratoires publics ou privés. 


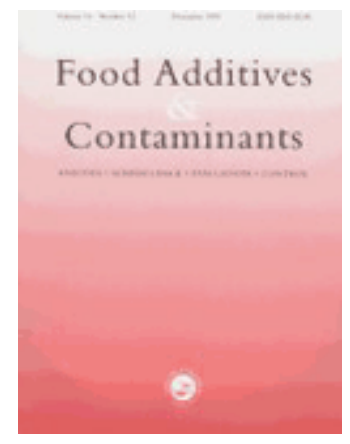

Reduction of Fusarium head blight and deoxynivalenol in wheat with early fungicide applications of prothioconazole

\begin{tabular}{|c|c|}
\hline Journal: & Food Additives and Contaminants \\
\hline Manuscript ID: & TFAC-2009-320.R1 \\
\hline Manuscript Type: & Special Issue \\
\hline $\begin{array}{l}\text { Date Submitted by the } \\
\text { Author: }\end{array}$ & 20-Nov-2009 \\
\hline Complete List of Authors: & $\begin{array}{l}\text { Edwards, Simon; Harper Adams University College } \\
\text { Godley, Nigel; Bayer CropScience }\end{array}$ \\
\hline Methods/Techniques: & Mycology \\
\hline Additives/Contaminants: & Mycotoxins - fusarium, Mycotoxins - trichothecenes \\
\hline Food Types: & Cereals and grain \\
\hline
\end{tabular}

\section{SCHOLARONE \\ Manuscripts}


Running title: Deoxynivalenol reduction with prothioconazole

\title{
Reduction of Fusarium head blight and deoxynivalenol in wheat with early fungicide applications of prothioconazole
}

\author{
Simon G Edwards ${ }^{\mathrm{a}}$ and Nigel P Godley ${ }^{\mathrm{b}}$ \\ Crop and Environment Research Centre, Harper Adams University College, \\ Newport, Shropshire TF10 8NB, UK \\ ${ }^{b}$ Bayer CropScience Region Europe, 16 rue Jean-Marie Leclair, 69009 Lyon, France
}

\begin{abstract}
Numerous studies have identified the benefit of fungicides applied at flowering (Zadoks Growth Stage (GS) 59-69) in the reduction of Fusarium head blight (FHB) and the reduction of deoxynivalenol (DON) in harvested wheat grain. Two experiments were performed to identify the ability of prothioconazole (Proline $\AA$, Bayer CropScience) at three timings to reduce FHB and resulting DON in harvested grain of wheat. Prothioconazole $\left(150 \mathrm{~g} \mathrm{ha}^{-1}\right)$ was applied to plots of wheat at GS31, 39 and 65 in a full factorial design. Plots were inoculated with Fusarium-infected oat grain at GS30 and mist-irrigated at GS65 to encourage head blight development. Plots were assessed for head blight symptoms at GS77 and harvested grain was analysed for yield, specific weight, thousand grain weight and DON. Factorial ANOVA identified prothioconazole applications at each timing resulted in significant reductions in FHB and DON. The control achieved with combinations of spray timings was additive with no significant interactions. The control of FHB at GS31, GS39 and GS65 was 50, 58 and 83\% respectively. The reduction in FHB achieved by all three timings combined was $97 \%$ compared to the fully untreated control plots. The reduction of DON after application of prothioconazole at GS31, GS39 and GS65 was 27,49 and $57 \%$ respectively. The application of prothioconazole at all three timings achieved $83 \%$ reduction of DON compared to the fully untreated control plots. These experiments have determined, for the first time, significant additional
\end{abstract}


head blight disease control and mycotoxin reduction with applications of a fungicide before flowering.

Keywords: Proline ${ }^{\circledR}$, yield, specific weight, thousand grain weight, fungicide timing, mycotoxins.

*Corresponding author. E-mail: sedwards@ harper-adams.ac.uk 


\section{Introduction}

Fusarium head blight (FHB) is an important disease of small grain cereals as it results in decreased yield, reduced grain quality (specific weight and thousand grain weight), processing quality and the presence of fusarium mycotoxins in harvested grain (Parry et al. 1995). The disease can be caused by several pathogens; the dominant ones are Fusarium graminearum (teleomorph Gibberella zeae), F. culmorum, F. poae, F. avenaceum, Microdochium nivale and M. majus. The Fusarium species produce a wide range of mycotoxins, the most important ones in wheat are deoxynivalenol (DON) and zearalenone. Both these mycotoxins are produced by $F$. graminearum and $F$. culmorum. Surveys have indicated that fusarium mycotoxins are common contaminants of wheat, however they usually occur at low concentrations (Edwards 2009). High concentrations can occur when weather conditions are conducive, in particular wet weather from flowering to harvest (Edwards 2009). DON causes reduced feed intake, reduced weight gain and vomiting in farm animals (Anon. 2004a). Nausea, vomiting, diarrhoea, abdominal pain, headache, dizziness and fever have been reported when high concentrations of DON were consumed by humans.

The European Commission set legislative limits for the fusarium mycotoxins including DON in cereal grains and cereal-based products intended for human consumption (Anon. 2006c). The maximum limit for DON in unprocessed wheat is $1250 \mu \mathrm{g} \mathrm{kg}^{-1}$; this limit applies to wheat placed on the market for processing for human consumption. Maximum limits are set on unprocessed cereals to avoid highly contaminated cereals entering the food chain and to encourage all measures to minimise fusarium mycotoxin contamination to be taken during the field stages of the production chain. The European Commission has also set guideline limits for fusarium mycotoxins in animal feed (Anon. 2006b). The lowest guidance limits have been set for pig feed owing to the high proportion of cereals in pig feed and their higher sensitivity to fusarium mycotoxins. The DON guidance value for complimentary and complete feedingstuffs for pigs is $900 \mu \mathrm{g} \mathrm{kg}^{-1}$. The legislation states that growers should use Good Agricultural Practice (GAP) to reduce mycotoxins in cereals. The principles of GAP were detailed in a Commission Recommendation (Anon. 2006a) which advises integrated control measures including crop rotation (avoiding host crops as previous crop), cultivation (ploughing to bury crop debris), choice of variety (planting Fusarium resistant varieties) and crop 
management to minimise plant stress, maintain plant nutrient balance and minimise lodging. The recommendation states that preventative measures should be used, and if necessary, application of fungicides can be used to control toxigenic Fusarium species.

Numerous studies have been conducted to evaluate the efficacy of fungicides to reduce fusarium head blight and resultant DON in harvested wheat (Boyacioglu et al. 1992; Edwards et al. 2001; Ellner 1997; Ioos et al. 2005; Mennitti et al. 2003; Simpson et al. 2001). These studies have highlighted that azole fungicides have the best efficacy, although it is important to note that the efficacy reported is highly variable between different azole fungicides and can be variable between experiments (Beyer et al. 2006). Tebuconazole is the most tested triazole and has been the industry standard for many years. Metconazole was introduced in 1994, and was shown to have similar efficacy to tebuconazole (Edwards et al. 2001; Ioos et al. 2005). More recently, prothioconazole was introduced in 2004, and this triazolinthione had the greatest inhibitory activity against $F$. graminearum in vitro of the fungicides tested (Klix et al. 2007) and has been shown to have high efficacy in field experiments (Paul et al. 2008).

Field experiments of fungicide efficacy against head blight have been conducted using either natural inoculum or inoculation. Experiments may also utilise irrigation systems to ensure conditions are conducive for head blight during the flowering period for infection to occur. Experiments using natural inoculum are usually conducted in fields with high disease pressure, for example following maize and minimum tillage, to maximise the probability of severe disease occurring. By spraying spores of Fusarium spp. at flowering followed by irrigation, severe disease can be ensured. Application of spores at flowering does not mimic natural infection, as the spores all arrive on the host crop at a single time, and such an application can not be used to test fungicides applied earlier in the growing season. An intermediate form of inoculation is the application of Fusarium inoculated grain to the experiment earlier in the season. The Fusarium on the inoculated grain sporulates over a long period of time, thus mimicking the natural inoculum present on the ground.

Fusarium spp. cause three diseases on small grain cereals, these are seedling blight, foot rot and head blight. Seedling blight is caused by Fusarium present on infected seed or within surrounding soil. This disease can result in pre- and postemergence death and diseased seedlings, as seedling grow this infection can develop 
into foot rot, a disease of the stem base. It is believed that inoculum for head blight can be from these two diseases, which occur earlier in the season or from crop debris, weeds and soil (Parry et al. 1995). The traditional timing for fungicides to control head blight has been at flowering (Zadoks et al. (1974) Growth Stage 59-69) when the infection primarily occurs. This is typically the third fungicide spray for wheat in the UK, designated T3. The early fungicide applications are at first or second node detectable (GS31-32; T1) and flag leaf fully emerged (GS39; T2). As part of a preliminary study (results not shown) using oat-grain-inoculum applied at stem extension (GS30), several fungicide programs with or without prothioconazole at T1 and T2 appeared to reduce head blight and DON. However, the spread of inoculum between plots may have reduced the ability of prothioconazole at $\mathrm{T} 1$ and $\mathrm{T} 2$ to reduce the disease and DON within these small plot experiments. It was therefore decided to conduct a full factorial design plus/minus prothioconazole at all three timings to maximise the statistical strength of the experiment to detect significant differences between treatments at each timing and any interaction between applications at each timing; and to use guard plots to minimise the spread of Fusarium inoculum between experimental plots.

The aim of these experiments was to measure the efficacy of prothioconazole $\left(150 \mathrm{~g} \mathrm{ha}^{-1}\right)$ applied as the formulated product Proline ${ }^{\circledR}$ (Bayer CropScience) at three timings (T1, T2 and T3) to reduce fusarium head blight incidence and DON content of harvest grain and to increase yield and grain quality.

\section{Material and methods}

\section{Experimental design}

A field experiment was conducted in 2007/08 and repeated in 2008/09. Experimental plots $(4 \times 12 \mathrm{~m})$ were separated by guard plots $(6 \times 12 \mathrm{~m})$. Winter wheat, cv. Solstice was sown and grown according to standard farm practice in Shropshire, UK. The experiments were designed as a split plot randomised block with eight treatments replicated four times. The design was a full factorial design of untreated and $0.61 \mathrm{ha}^{-1}$ Proline ${ }^{\circledR}$ (ai prothioconazole $250 \mathrm{~g} \mathrm{l}^{-1}$ ) treated plots at three timings: T1 (GS 31; first node detectable), T2 (GS39; flag leaf fully emerged) and T3 (GS65; mid-anthesis). The rate of Proline ${ }^{\circledR}$ applied at each timing was 0.75 of the recommended single dose. Treatments are listed in Table 1. T1 and T2 treatments were fully randomised (whole plot) and T3 treatments were randomised between sub-plots ( $2 \times 12 \mathrm{~m})$. All 
fungicides were applied in $2001 \mathrm{ha}^{-1}$ water using an 'AZO' knapsack sprayer with $110^{\circ}$ flat fan nozzles. All guard plots received a robust fungicide regime containing prothioconazole to minimise spread of inoculum between treated plots. Treated plots were mist irrigated for 17 hours each day (05:00-22:00) for five days from 1 day after the T3 fungicide was applied to optimise conditions for FHB infection.

\section{Artificial inoculation}

Three isolates each of $F$. graminearum (Fg75/11, Fg113, Fg2001/169) and $F$. culmorum (Fc2001/158, Fc2001/152, Fc103) were taken from the culture collection at Harper Adams University College. Isolates were sub-cultured on fresh potato dextrose agar (PDA, Merck KGaA, Germany) and after 5 days growth at room temperature used to seed $500 \mathrm{ml}$ of potato dextrose broth (PDB, Merck) in 2-litre flasks. Flasks were shaken twice a day by hand for 5 days. One $\mathrm{kg}$ of oats were added to $100 \mathrm{ml}$ of deionised water in a 400 x $550 \mathrm{~mm}$ autoclave bag, soaked for 1 hour at room temperature and then autoclaved for $1 \mathrm{~h}$ at $121^{\circ} \mathrm{C}$. One hundred $\mathrm{ml}$ of inoculated PDB was used to inoculate each bag of sterilised oat grains. Bags were gently mixed to distribute the inoculum and incubated for 2 weeks at ca. $20^{\circ} \mathrm{C}$. Inoculated oat grains were mixed together to produce a composite inoculum and treated plots were inoculated with $19 \mathrm{~g} \mathrm{~m}^{-2}$ of oat grain inoculum at GS 30 (stem extension).

\section{Disease assessment}

Head blight assessments were completed on all plots at late milk (GS 77). Incidence of FHB was calculated as number of infected heads per square metre based on counts conducted in ten quadrats $\left(33 \mathrm{~cm}^{-2}\right)$ within each plot. Data was converted to \% FHB incidence based on average number of heads per square metre.

\section{Yield assessment}

At maturity, each plot was harvested using a plot combine and the moisture content and total grain yield recorded. Yield was adjusted to tonnes $\mathrm{ha}^{-1}$ at $15 \%$ moisture content. One kilogram grain samples were taken for determination of grain quality parameters; thousand grain weight (TGW) and specific weight (SW). Grain samples were then milled (ZM100 mill with $1 \mathrm{~mm}$ screen, Retsch UK Ltd, Leeds), mixed in a tumbler mixer and laboratory samples removed for DON analysis. 


\section{DON analysis}

DON was quantified using a DON FAST ELISA kit (R-Biopharm Rhone, Glasgow) according to the manufacturer's instructions. Eight grams of flour were extracted in $40 \mathrm{ml}$ deionised water.

\section{Statistical analysis}

The statistical package used for all data analysis was Genstat (Version 12, Lawes Agricultural Trust, Rothamsted, UK). Percentage FHB incidence was logit transformed and DON data $\log 10$ transformed to obtain normally distributed residuals. Data from both experiments was first analysed by split-plot analysis of variance (ANOVA) with year as whole plot and treatment as sub-plot. This identified if there was a significant difference between years, treatments and an interaction between year and treatment. Both experiments were then analysed together using a split plot factorial $(\mathrm{T} 1 * \mathrm{~T} 2 * \mathrm{~T} 3)$ ANOVA with a block structure of block nested within year; $\mathrm{T} 1 * \mathrm{~T} 2$ as whole plots and $\mathrm{T} 3$ as sub-plots.

\section{Results}

There was no significant difference in TGW between the two field experiments conducted in 2007/08 and 2008/09, for all other parameters measured there was a highly significant difference $(\mathrm{p}<0.001)$ between the two experiments $($ Table 2$)$. For FHB disease incidence the predicted mean for 2008 and 2009 was 0.7 and $15 \%$ respectively. There was a corresponding impact on DON, yield and SW (Table 2). Treatment differences were highly significant $(\mathrm{p}<0.001)$ for all parameters. There was a significant interaction between year and treatment for yield $(\mathrm{p}=0.029)$ and $\mathrm{SW}$ $(\mathrm{p}=0.037)$ but not for FHB incidence, DON or TGW. As the interactions were either not significant or were much less significant than the main effects then the treatment differences were broadly consistent between years. When each experiment was analysed by ANOVA the residual mean squares were similar, it was therefore acceptable to analyse the datasets for both years together (block nested within year) and these results are presented (Table 3). Factorial analysis identified that there was no significant interactions between fungicide timings for any parameter measured. 
Table 3 shows the p-values and prothioconazole predicted mean values as percentage differences compared to the untreated control for each fungicide application timing.

Each application of prothioconazole significantly $(\mathrm{p}<0.05)$ reduced the incidence of FHB at GS 77 and DON at harvest. The most effective timing was T3 with $83 \%$ and $57 \%$ reduction respectively (Table 3 ) and the cumulative benefit of three applications of prothioconazole resulted in the greatest observed reductions of 97\% and $83 \%$ respectively compared to the untreated controls (Figure 1). These values are close to the calculated cumulative reduction based on the individual T1, T2 and $\mathrm{T} 3$ reductions presented in Table 2 (96\% and $84 \%$ respectively).

Overall yield, specific weight (SW) and thousand grain weight (TGW) were as expected considering the severity of FHB in the untreated controls. Factorial analysis identified that all fungicide treatments resulted in a highly significant $(\mathrm{p}<0.001)$ increases in yield, SW and TGW, except for SW (p=0.050) and TGW (p=0.005) with a T1 application (Table 3). Again, benefits of prothioconazole were cumulative resulting in greatest increases in yield, SW and TGW from the application of prothioconazole at all three timings. Compared to the untreated control the application of prothioconazole at all three timings resulted in a yield increase of 4.6 ton $\mathrm{ha}^{-1}(98 \%)$. The greatest contribution to increased yield was from the $\mathrm{T} 2$ application (26\%). Compared to the untreated control the application of prothioconazole at all three timings resulted in an increase of SW of $11.4 \mathrm{~kg} \mathrm{~h}^{-1}$ (19\%) and an increase in TGW of $13.4 \mathrm{~g}(38 \%)$.

\section{Discussion}

As part of a preliminary study (results not shown) using oat-grain-inoculum at GS30, several fungicide programs with or without prothioconazole at T1 and T2 appeared to reduce head blight and DON in 2006 but not in 2007. These studies were conducted in a standard small plot $(2 \times 12 \mathrm{~m})$ randomised block design. The difference observed between 2006 and 2007 may have been due to large differences in rainfall. In 2006, the period from T1 application to end of flowering was relatively dry with only 86 $\mathrm{mm}$ of rainfall of which only $8 \mathrm{~mm}$ fell during flowering. In the following year over the same period there was $172 \mathrm{~mm}$ rainfall, including $64 \mathrm{~mm}$ over 3 days during flowering. Rainfall events are known to result in splash dispersal of Fusarium conidia (Jenkinson and Parry 1994) and stimulate release of Gibberella zeae ascospores (Paulitz 1996). It was therefore concluded that in 2007, the high rainfall resulted in 
any reduction in head blight inoculum as a result of $\mathrm{T} 1$ and $\mathrm{T} 2$ fungicide sprays were masked due the dispersal of inoculum between plots during subsequent periods of high rainfall. It was therefore decided to modify the experimental design to include guard plots to minimise spread of inoculum between treated plots. As the inoculum pressure at flowering would be the same for fungicide programs with the same T1 and $\mathrm{T} 2$ treatments, the treatments were paired together to provide whole plots treated with combinations of plus/minus prothioconazole at $\mathrm{T} 1$ and $\mathrm{T} 2$ and subplots plus/minus prothioconazole at T3. This reduced the number of guard plots required and therefore increased the potential size of guard plots for a given experimental area available.

The use of inoculated oat grain as inoculum applied early in the wheat growing season and the use of guard plots to minimise the spread of inoculum between plots allowed the successful identification of the benefit of prothioconazole applied at all three timings. The reduction in head blight and DON was greatest from an application of prothioconazole at T3 and least at T1. Prothioconazole resulted in $83 \%$ reduction of head blight and $57 \%$ reduction of DON in harvested grains with a single application of three quarter dose at GS65 (T3 timing). This compares well with previous studies, where on average tebuconazole and metconazole applied at full rate, resulted in 58\% ( $\mathrm{n}=7$ experiments) and $60 \%(\mathrm{n}=24$ experiments) DON reduction respectively (Beyer, 2006). The timing of application is critical at flowering with a drop in fungicide efficacy as the fungicide is applied further away from the timing of infection (Pirgozliev et al. 2008).

Two previous studies using controlled environment and glasshouse experiments indicated that early applications of fungicides could reduce FHB and in one study, DON (Greenfield and Rossall 2000; Hutcheon and Jordan 1992). However, statistical analysis was not presented and the studies were not repeated. In a field experiment on disease control of leaf spot and head blight with natural infection, there was no significant reduction of FHB with tebuconazole applied at GS39 but there was a significant reduction in DON (40\%) in one year out of three (Wiersma and Motteberg 2005).

It is not clear how fungicide applications before head emergence could reduce head blight and subsequent DON. For the T1 application the likely mechanism is in the reduction of Fusarium on the young crop, particularly the dead outer leaf sheaths and on surrounding crop debris and soil. At T2, most fungicide is deposited on the upper leaf canopy. At this timing the fungicide may reduce the number of Fusarium 
spores on the leaf surfaces. There is evidence of natural suppression of FHB from saprophytic microflora (Liggitt et al. 1997); prothioconazole may benefit the competitors of Fusarium spp. due to its high inhibitory activity towards this genus (Klix et al. 2007). As prothioconazole is systemic and the T2 application is applied within 7-14 days of head emergence, there may also be some direct inhibition of infection from prothioconazole translocated to the wheat heads from the T2 application.

In contrast, some strobilurin fungicides have been shown to increase DON when applied during flowering (Simpson et al. 2001). This may be due to the disruption of natural suppression of Fusarium spp. by other head blight pathogens (Microdochium spp.) (Jennings et al. 2000) and saprophytic microflora (Liggitt et al. 1997). Ellner (2006) reported that applications of some strobilurins before flowering (GS33-55) could also result in an increase in DON.

Increases in grain quality were also greatest after a T3 application of prothioconazole and least from a T1 application. This correlation would indicate that the increase is grain quality was associated with the reduction in head blight. The greatest increase in yield was associated with the T2 application of prothioconazole. As the greatest control of FHB was from the T3 timing, this would indicate that the control of other pathogens was a major contributing factor to the yield benefit from application of prothioconazole at T2. This is likely to be partially due to the control of foliar pathogens, such as Septoria tritici, on the flag leaf, as this leaf is the predominant source of yield potential in wheat (Milne et al. 2007).

There was a large difference in the severity of head blight between the two years even though the experimental design was unchanged. This is likely to be due to differences in environmental conditions during key crop growth stages for head blight infection. As well as flowering, when both experiments were mist irrigated, key environmental conditions are during the spring when spore production occurs and the week before flowering when spores can be dispersed onto the emerging wheat heads (De Wolf et al. 2003). In late spring of 2009 it was observed that oat grains were covered with large perithecia, indicating that conditions had been conducive for ascospore production by Gibberella zeae. These perithecia were more prolific and larger than observed in the previous year. Two other factors may have increased the disease pressure in 2009. Firstly, in the week before flowering there were 5 days with rainfall greater than $5 \mathrm{~mm}$ whereas in 2008 there was no rainfall in the same period. 
Secondly, the average temperature during mist irrigation in 2009 was $16.3^{\circ} \mathrm{C}$ compared to $13.4^{\circ} \mathrm{C}$ in 2008 . The optimum temperature for $F$. graminearum growth is $25^{\circ} \mathrm{C}$ (Brennan et al. 2003). Under the high disease pressure which occurred in 2009 a higher rate of prothioconazole would be required to reduce the DON concentration at harvest to below the legal limit of $1250 \mu \mathrm{g} \mathrm{kg}^{-1}$.

The ideal method to control crop diseases is through host resistance. Resistance to Fusarium head blight is polygenic and several resistance loci are closely linked to negative agronomic traits (Bai and Shaner 2004). Consequently the availability of economically viable varieties with partial resistance to head blight is limited in many wheat growing regions of the world. At least for the short to medium term, fungicides will continue to play a key role in the reduction of fusarium mycotoxins in small grain cereals. This study has provided clear evidence that application of prothioconazole early in fungicide programs (ie before head emergence) can have a significant contribution to reducing head blight and subsequent DON contamination of harvested grain. The benefit of prothioconazole applied at each timing was additive, with control achieved from all three timings was $97 \%$ reduction of FHB and $83 \%$ reduction of DON. Growers should therefore consider Fusarium-active fungicides within all application timings as part of an integrated control strategy. Earlier fungicide applications will be particularly beneficial when weather conditions at flowering are not conducive to application of a head blight fungicide at the optimum timing.

\section{Acknowledgements}

SGE acknowledges technical support of the Crop and Environment Research Centre, in particular; Matthew Rodenhurst, Fikirini Ramadhani, Samuel Imathiu and Danielle Henderson and the funding of field experiments by Bayer CropScience.

\section{References}

Anon. 2004a. Opinion of the scientific panel on the contaminants in the food chain on a request from the Commission related to deoxynivalenol (DON) as undesirable substance in animal feed. The EFSA Journal 73:1-41. Anon. 2006a. Commission recommendation of 17 August 2006 on the prevention and reduction of Fusarium toxins in cereals and cereal products. Official Journal of the European Union L234:35-40. 
Anon. 2006b. Commission recommendation on the presence of deoxynivalenol, zearalenone, ochratoxin A, T-2 and HT-2 and fumonisins in products intended for animal feeding. Official Journal of the European Union L229:7-9.

Anon. 2006c. Commission Regulation (EC) No 1881/2006 setting maximum levels of certain contaminants in foodstuffs. Official Journal of the European Union L364:5-24. Bai GH, Shaner G. 2004. Management and resistance in wheat and barley to Fusarium head blight. Annual Review of Phytopathology 42:135-161.

Beyer M, Klix MB, Klink H, Verreet JA. 2006. Quantifying the effects of previous crop, tillage, cultivar and triazole fungicides on the deoxynivalenol content of wheat grain - a review. Journal of Plant Diseases and Protection 113:241-246.

Boyacioglu D, Hettiarachchy NS, Stack RW. 1992. Effect of 3 Systemic Fungicides on Deoxynivalenol (Vomitoxin) Production by Fusarium graminearum in Wheat. Canadian Journal of Plant Science 72:93-101.

Brennan JM, Fagan B, van Maanen A, Cooke BM, Doohan FM. 2003. Studies on in vitro growth and pathogenicity of European Fusarium fungi. European Journal of Plant Pathology 109:577-587.

De Wolf ED, Madden LV, Lipps PE. 2003. Risk assessment models for wheat Fusarium head blight epidemics based on within-season weather data.

Phytopathology 93:428-435.

Edwards SG. 2009. Fusarium mycotoxin content in UK organic and conventional wheat. Food Additives and Contaminants 26:496-506.

Edwards SG, Pirgozliev SR, Hare MC, Jenkinson P. 2001. Quantification of trichothecene-producing Fusarium species in harvested grain by competitive PCR to determine efficacies of fungicides against fusarium head blight of winter wheat. Applied and Environmental Microbiology 67:1575-1580.

Ellner FM. 1997. Influence of fungicide treatment on deoxynivalenol content in winter wheat artificially infected with Fusarium culmorum. Cereal Research Communications 25:735-737.

Ellner FM. 2006. Results of long-term field studies into the effect of strobilurin containing fungicides on the production of mycotoxins in several winter wheat varieties. Mycotoxin Research 21:112-115.

Greenfield JE, Rossall S. 2000. The effect of a range of novel and established fungicides on Fusarium growth and mycotoxin production. International Conference on Pests and Diseases Brighton, England, pp 483-486 
Hutcheon JA, Jordan VWL. 1992. Fungicide timing and performance for fusarium control in wheat. Brighton Crop Protection Conference on Pests and Diseases Brighton, England, pp 633-638

Ioos R, Belhadj A, Menez M, Faure A. 2005. The effects of fungicides on Fusarium spp. and Microdochium nivale and their associated trichothecene mycotoxins in French naturally-infected cereal grains. Crop Protection 24:894-902.

Jenkinson P, Parry DW. 1994. Splash Dispersal of Conidia of Fusarium-Culmorum and Fusarium-Avenaceum. Mycological Research 98:506-510.

Jennings P, Turner JA, Nicholson P. 2000. Overview of fusarium ear blight in the UK - effect of fungicide treatment on disease control and mycotoxin production. International Conference on Pests and Diseases Brighton, England, pp 707-712 Klix MB, Verreet JA, Beyer M. 2007. Comparison of the declining triazole sensitivity of Gibberella zeae and increased sensitivity achieved by advances in triazole fungicide development. Crop Protection 26:683-690.

Liggitt J, Jenkinson P, Parry DW. 1997. The role of saprophytic microflora in the development of Fusarium ear blight of winter wheat caused by Fusarium culmorum. Crop Protection 16:679-685.

Mennitti AM, Pancaldi D, Maccaferri M, Casalini L. 2003. Effect of fungicides on Fusarium head blight and deoxynivalenol content in durum wheat grain. European Journal of Plant Pathology 109:109-115.

Milne A, Paveley N, Auclsley E, Parsons D. 2007. A model of the effect of fungicides on disease-induced yield loss, for use in wheat disease management decision support systems. Annals of Applied Biology 151:113-125.

Parry DW, Jenkinson P, McLeod L. 1995. Fusarium ear blight (Scab) in small-grain cereals - a review. Plant Pathology 44:207-238.

Paul PA, Lipps PE, Hershman DE, McMullen MP, Draper MA, Madden LV. 2008. Efficacy of triazole-based fungicides for Fusarium head blight and deoxynivalenol control in wheat: A multivariate meta-analysis. Phytopathology 98:999-1011.

Paulitz TC. 1996. Diurnal release of ascospores by Gibberella zeae in inoculated wheat plots. Plant Disease 80:674-678.

Pirgozliev SR, Ray RV, Edwards SG, Hare MC, Jenkinson P. 2008. Effect of timing of fungicide application on the development of Fusarium head blight and the accumulation of deoxynivalenol (DON) in winter wheat grain. Cereal Research Communications 36:289-299. 
Simpson DR, Weston GE, Turner JA, Jennings P, Nicholson P. 2001. Differential control of head blight pathogens of wheat by fungicides and consequences for mycotoxin contamination of grain. European Journal of Plant Pathology 107:421-431. Wiersma JJ, Motteberg CD. 2005. Evaluation of five fungicide application timings for control of leaf-spot diseases and fusarium head blight in hard red spring wheat.

Canadian Journal of Plant Pathology-Revue Canadienne De Phytopathologie 27:2537.

Zadoks J, Chang T, Konzak C. 1974. A decimal code for the growth stages of cereals. Weed Research 14:415-421. 
Table 1. Factorial split-plot design for winter wheat FHB field experiment with three spray timings (T1, T2 and T3) when plots were untreated or treated with $150 \mathrm{~g} \mathrm{ha}^{-1}$ prothioconazole. $\mathrm{T} 1 * \mathrm{~T} 2$ combinations were whole plots and $\mathrm{T} 3$ treatments were applied to sub-plots.

\begin{tabular}{cclll}
\hline Treatment & Whole plot & \multicolumn{1}{c}{ T1 (GS31) } & T2 (GS39) & \multicolumn{1}{c}{ T3 (GS65) } \\
\hline 1 & 1 & Untreated & Untreated & Untreated \\
2 & 1 & Untreated & Untreated & Prothioconazole \\
3 & 2 & Prothioconazole & Untreated & Untreated \\
4 & 2 & Prothioconazole & Untreated & Prothioconazole \\
5 & 3 & Untreated & Prothioconazole & Untreated \\
6 & 3 & Untreated & Prothioconazole & Prothioconazole \\
7 & 4 & Prothioconazole & Prothioconazole & Untreated \\
8 & 4 & Prothioconazole & Prothioconazole & Prothioconazole \\
\hline
\end{tabular}

Table 2. Overall mean \% FHB incidence, DON, yield, specific weight (SW) and thousand grain weight (TGW) for winter wheat field experiments conducted in 2007/08 and 2008/09. Values are back-transformed means for incidence and DON data. $P$-values are presented for year $(n=2)$, treatment $(n=8)$ and the interaction between these two main factors.

\begin{tabular}{cccccc}
\hline & $\begin{array}{c}\text { \% FHB } \\
\text { incidence }\end{array}$ & $\begin{array}{c}\text { DON } \\
\left(\mu \mathrm{g} \mathrm{kg}^{-1}\right)\end{array}$ & $\begin{array}{c}\text { Yield } \\
\left(\text { ton ha }^{-1}\right)\end{array}$ & $\begin{array}{c}\text { SW } \\
\left(\mathrm{kg} \mathrm{hl}^{-1}\right)\end{array}$ & $\begin{array}{c}\text { TGW } \\
(\mathrm{g})\end{array}$ \\
\hline $2007 / 08$ & 0.7 & 1816 & 8.7 & 70.4 & 42.9 \\
$2008 / 09$ & 14.8 & 13122 & 6.1 & 63.0 & 42.7 \\
\hline $\begin{array}{c}\text { Year p-value } \\
\text { Treatment } \\
\text { p-value }\end{array}$ & $<0.001$ & $<0.001$ & $<0.001$ & $<0.001$ & 0.864 \\
$\begin{array}{c}\text { Year*Treatment } \\
\text { p-value }\end{array}$ & 0.001 & $<0.001$ & $<0.001$ & $<0.001$ & $<0.001$ \\
\hline
\end{tabular}


Table 3. Predicted mean \% FHB incidence, DON, yield, specific weight (SW) and thousand grain weight (TGW) for untreated (Unt) and prothioconazole (Proth; $150 \mathrm{~g} \mathrm{ha}^{-1}$ ) treated plots at each fungicide application timing (T1, T2 and T3). Values are back-transformed means for incidence and DON data. P-values and percentage differences are shown in parenthesis.

\begin{tabular}{|c|c|c|c|c|c|}
\hline \multirow{2}{*}{$\begin{array}{c}\text { Spray } \\
\text { Timing }\end{array}$} & $\%$ FHB incidence & $\begin{array}{c}\mathrm{DON} \\
\left(\mu \mathrm{g} \mathrm{kg}^{-1}\right)\end{array}$ & $\begin{array}{c}\text { Yield } \\
{\left.\text { (ton } \mathrm{ha}^{-1}\right)}\end{array}$ & $\begin{array}{c}\mathrm{SW} \\
\left(\mathrm{kg} \mathrm{h}^{-1}\right)\end{array}$ & $\begin{array}{l}\text { TGW } \\
(\mathrm{g})\end{array}$ \\
\hline & Proth & Proth & Proth & Proth & Proth \\
\hline $\mathrm{T} 1$ & $\begin{array}{lr}4.8 & 2.4 \\
(p<0.001 ; & -50)\end{array}$ & $\begin{array}{c}5715 \quad 4169 \\
(p=0.03 ;-27)\end{array}$ & $\begin{array}{l}6.8 \quad 8.0 \\
(p<0.001 ; 18)\end{array}$ & $\begin{array}{c}67.5 \\
(p=0.05 ; 2.4)\end{array}$ & $\begin{array}{l}44.2 \quad 41.3 \\
(p=0.005 ; 7.1)\end{array}$ \\
\hline $\mathrm{T} 2$ & $\begin{array}{lr}5.2 & 2.2 \\
(\mathrm{p}<0.001 ; & -58)\end{array}$ & $\begin{array}{lc}6823 & 3499 \\
(\mathrm{p}<0.001 ; & -49)\end{array}$ & $\begin{array}{lc}6.5 & 8.2 \\
(\mathrm{p}<0.001 ; 26)\end{array}$ & $\begin{array}{l}68.6 \quad 64.8 \\
(p<0.001 ; 5.8)\end{array}$ & $\begin{array}{l}45.3 \quad 40.3 \\
(p<0.001 ; 12.4)\end{array}$ \\
\hline T3 & $\begin{array}{lr}8.1 & 1.4 \\
(p<0.001 ; & -83)\end{array}$ & $\begin{array}{ll}7482 & 3184 \\
(\mathrm{p}<0.001 ; & -57)\end{array}$ & $\begin{array}{lr}6.6 & 8.2 \\
(\mathrm{p}<0.001 ; 24)\end{array}$ & $\begin{array}{l}69.5 \\
(\mathrm{p}<0.001 ; 8.9)\end{array}$ & $\begin{array}{lr}46.0 & 39.5 \\
(\mathrm{p}<0.001 ; 16.5)\end{array}$ \\
\hline
\end{tabular}


A.

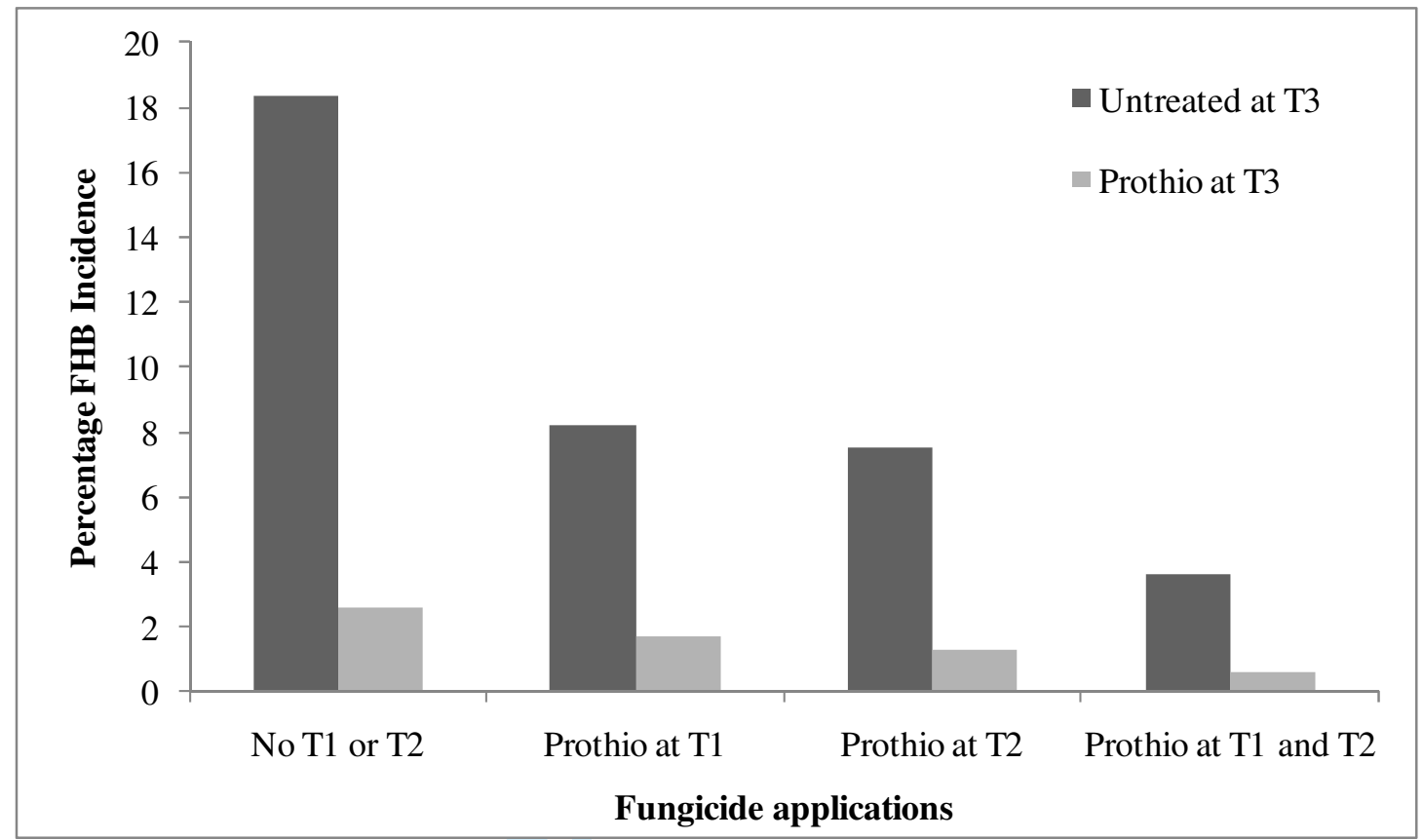

B.

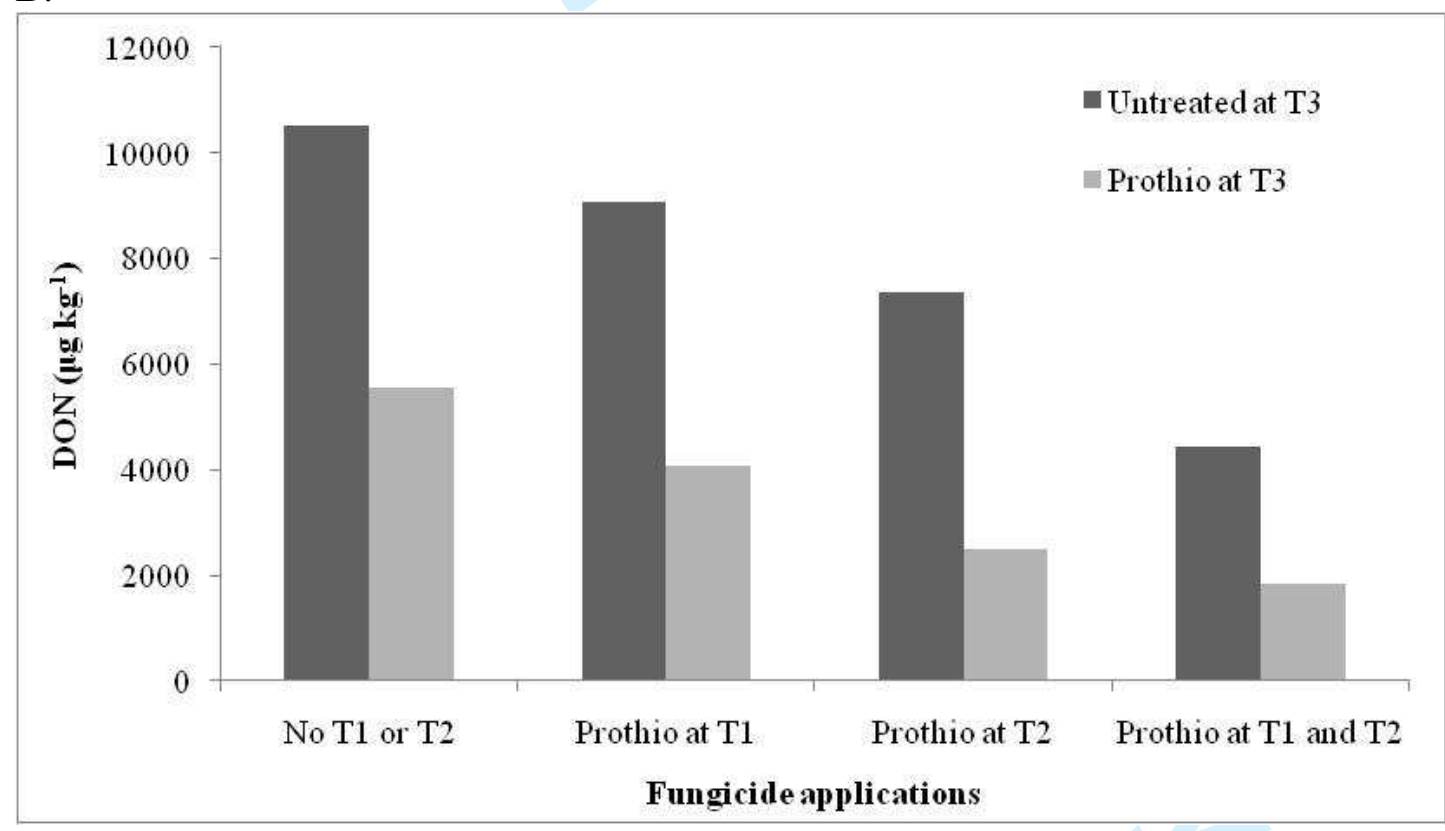

Figure 1. Back-transfomed mean percentage Fusarium head blight incidence (A) and DON concentration (B) for winter wheat plots untreated or treated with prothio (prothioconazole; $150 \mathrm{~g} \mathrm{ha}^{-1}$ ) at three fungicide application timings; T1, T2 and T3. Replication was two years $\mathrm{x}$ four blocks. 